\title{
Keeping Sensory Cells and Evolving Neurons to Connect Them to the Brain: Molecular Conservation and Novelties in Vertebrate Ear Development
}

\author{
B. Fritzsch K.W. Beisel \\ Creighton University, Department of Biomedical Sciences, Omaha, Nebr., USA
}

\section{Key Words}

Ear evolution · Hair cell · Mechanosensory neurons ·

Molecular evolution - Mechanosensory channels

\begin{abstract}
The evolution of the mechanosensory cellular module and the molecular details that regulate its development has included morphological modifications of these cells as well as the formation of larger assemblies of mechanosensory cell aggregates among metazoans. This has resulted in a wide diversity of mechanosensory organs. The wide morphological diversity of organs, including the associated morphological modifications of the mechanosensory cells, suggests parallel evolution of these modules and their associated organs. This morphological diversity is in stark contrast to the molecular conservation of developmental modules across phyla. These molecular data suggest that the evolution of mechanosensory transduction might have preceded that of distinct cellular differentiation. However, once a molecular network governing development of specialized cells involved in mechanosensory transduction evolved, that molecular network was preserved across phyla. Present data suggest that at least the common ancestor of triplo-
\end{abstract}

\section{KARGER}

Fax + 41613061234

E-Mail karger@karger.ch

www. karger.com
(C) 2004 S. Karger AG, Basel

Accessible online at: www. karger.com/bbe blastic organisms, perhaps even the common diploblastic ancestor of bilaterian metazoans, had molecular and cellular specializations for mechanosensation. It is argued that the evolution of multicellular organs dedicated to specific aspects of mechanosensation, such as gravity and sound perception, are evolutionary transformations that build on this conserved molecular network for cellular specialization, but reflect distinct morphological solutions. We propose that the sensory neurons, connecting the craniate ear with the brain, are a derived feature of craniates, and possibly chordates, that came about through diversification of the lineage forming mechanosensory cells during development. This evolutionarily late event suggests a heterochronic shift, so that sensory neurons develop in mammals prior to mechanosensory hair cells. However, sensory neuron development is connected to hair cell development, likely in a clonal relationship. The theme of cellular conservation is reiterated in two examples of chordate otic diversification: the evolution of the horizontal canal system and the evolution of the basilar papilla/cochlea. It is suggested that here again, cellular multiplication and formation of a special epithelium predates the functional transformation to an 'organ' system for horizontal angular acceleration and sound pressure reception, respectively. Overall, evolu-
B. Fritzsch

Creighton University

Department of Biomedical Sciences

Omaha, NE 68178 (USA)

Tel. +1 402280 2915, Fax +1 402280 5556, E-Mail fritzsch@creighton.edu 
tion of the vertebrate ear needs to be understood as an interplay between and utilization of two gene networks or modules. One is at the level of the molecularly and developmentally conserved mechanosensory cellular module. The other is an increased complexity in the morphology of both adult mechanosensory cells and organs by the addition of end-stage and novel features and associated gene networks to detect specific aspects of mechanosensory stimuli.

Copyright @ 2004 S. Karger AG, Base

\section{Introduction}

'There are good indicators ... that this search for basic mechanisms will not be in vain. The use of sensory cells bearing kinocilia, the ultrastructure of which is intimately related to the cell' polarization of sensitivity, is now known to be common to groups as far apart as Coelenterata, Mollusca and Vertebrata.' [Mark1, 1974].

Evolution of the inner ear was originally discerned through comparisons of the morphological changes in a wide variety of species within the Bilateria and the fossil record. With the recent incorporation of genomic, transcriptome, proteomic and interactome approaches into 'evo-devo' analyses, these comparisons can now be made at the molecular level to facilitate a greater understanding of how external 'sensory-like' structures in unicellular organisms evolved into the multi-endorgan-containing bony labyrinth known as the inner ear of vertebrates. Perception of external stimuli by an organism is fundamentally an ancient problem that requires integration of physical, biochemical, and genetic parameters to maintain associated adaptational advantages. Identification of the primordial 'inner ear' can now be logically inferred from functionally based molecular networks [Fritzsch and Beisel, 2001]. The identity of the precise structure in unicellular organisms that evolved into mechanosensory cells is not known and not likely to be determined. The simplest fundamental mechanosensory structure is represented by a cellular module, consisting of a ciliated sensory neuron and its associated non-sensory cells. We will use the ciliated neuron of Caenorhabditis elegans and that of Drosophila melanogaster to represent the prototypical sensory module and, based on this, reconstruct conserved molecular and genetic regulatory networks and more ancient mechanosensory elements, as well as evolutionary changes leading to the formation of the sophisticated and complex mammalian inner ear.
The inner ear of craniate vertebrates is a system ranging from one to three interconnected tubes communicating with a corresponding number of recesses. Together, this system of tubes and recesses is referred to as the otic labyrinth [Retzius, 1884; de Burlet, 1934; Lewis et al., 1985]. The tubes are the semicircular canals, which are dedicated to detecting angular acceleration through their crista organs, and the recesses contain otoconia-bearing organs, which are utilized for perceiving linear acceleration. An additional organ, the basilar papilla, first appears in sarcopterygians [Fritzsch, 1992, 2003] and is apparently specialized in tetrapods to detect sound pressure. Throughout the evolution of the inner ear, endorgans have segregated and specialized. The largest number of endorgans appears to be the nine endorgans of gymnophionan amphibians: three semicircular canal cristae, a utricle, a saccule, a lagena, a basilar papilla, a neglected papilla and an amphibian papilla, probably all dedicated to detecting specific aspects of mechanical stimulation [Sarasin and Sarasin, 1892; Fritzsch and Wake, 1988]. The selective perception of angular acceleration, linear acceleration, or sound pressure stimulation is a function of ear morphology in combination with the acellular coverings of the sensory epithelia: the cupula in the semicircular canal cristae, the otoconia in the organs sensing linear acceleration, and the tectorial membrane in sound pressure receivers [Lewis et al., 1985; Goodyear and Richardson, 2002]. An understanding of ear evolution, therefore, requires an appreciation of how the increased morphological complexity (from a single tube to three tubes, along with their associated recesses) and changes in the acellular coverings of the sensory epithelia affect the specificity and sensitivity of stimulus acquisition in a variable number of these sensory epithelia and thus benefit the species in question. Proper gravistatic and sound orientation is crucial for survival, which includes both predation and predator avoidance.

Overall, the changes in the inner ear of craniates form a morphological series of alterations, starting with the least complicated ear to be found in extant craniates, that of hagfishes. Derived patterns in all crown groups of vertebrates are characterized by increasingly segregated and more specialized sensory epithelia (fig. 1). For example, mammals have evolved a long, coiled cochlea, which enables them to perceive sound over a wider frequency range than other vertebrates [Lewis et al., 1985]. Among other vertebrate taxa, amphibians are unique in their evolution of a distinct amphibian sensor dedicated to sound perception: the amphibian papilla [de Burlet, 1934]. Analysis of ear development in those amphibian taxa that pos- 


\section{Anamniotic ear evolution}

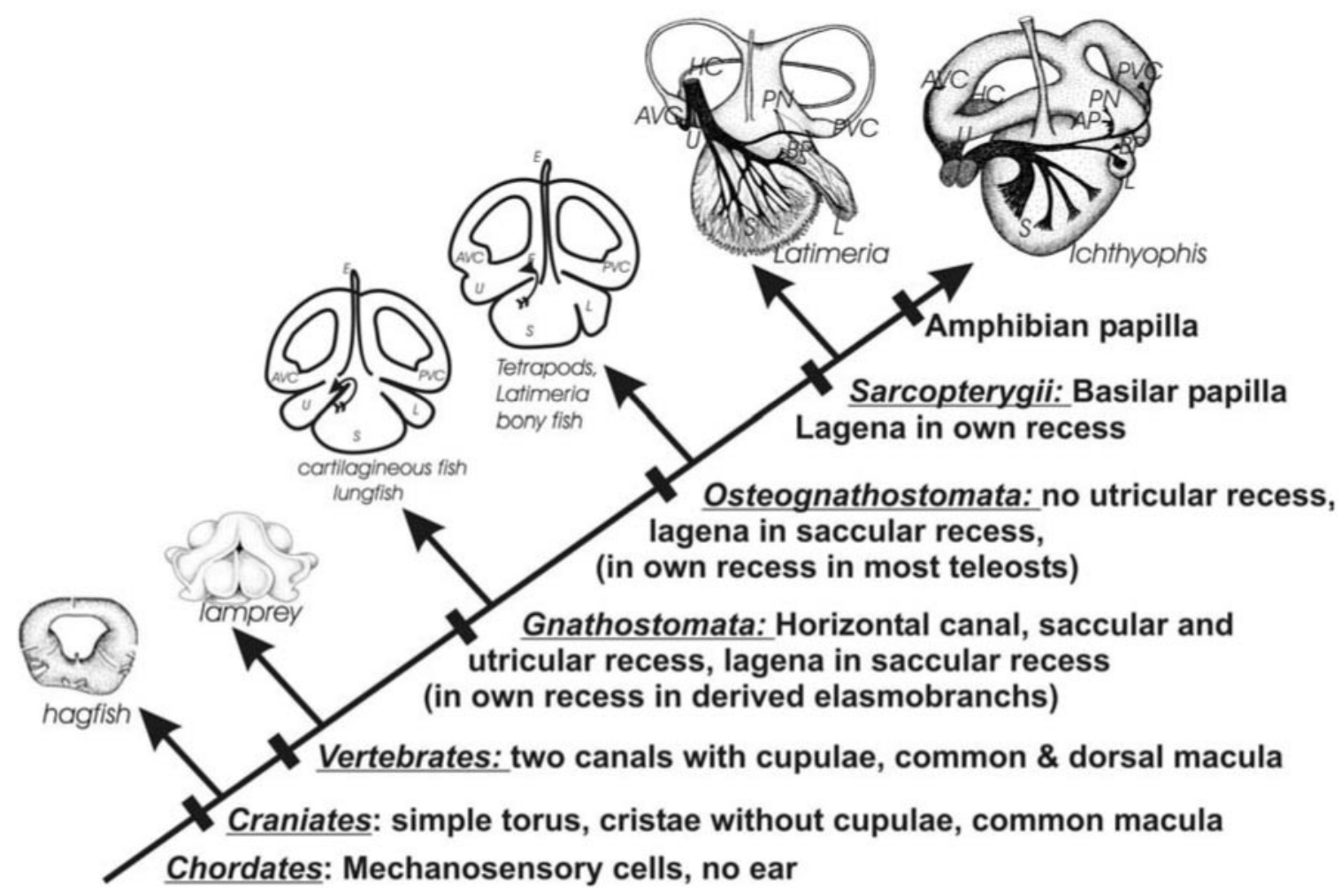

Fig. 1. The morphological evolution of the craniate ear is shown. It is assumed that the outgroup had mechanosensory cells, but no ear. The hagfish ear shows a single torus with only three sensory cell patches, two rings of hair cells forming the anterior and posterior sensory canal crista and the common macula. The sensory cristae of hagfish have no cupula, a unique and likely primitive feature of chordates. Evolution results in multiplication of endorgans through developmental segregation, culminating in a total of 9 endorgans in certain limbless amphibians. In parallel, the ear becomes a labyrinth of as many as three distinct semicircular canals and three distinct

recesses harboring the otoconia/otolith bearing saccular, lagenar and utricular macula. These recesses form two distinct patterns: one pattern is found among chondrychthians and lungfishes; the second pattern is found in actinopterygian and sarcopterygian fish. Sarcopterygian fishes have evolved a separate organ, the basilar papilla, that exists in most tetrapods and that becomes the mammalian cochlea. AP, amphibian papilla; AVC, anterior vertical crista; BP, basilar papilla; HC, horizontal crista; L, lagena; PN, papilla neglecta; PVC, posterior vertical canal; S, saccule; U, utricle. [Modified from Fritzsch and Beisel, 2001; Fritzsch, 2003].

sess all vertebrate sensory epithelia suggests that the amphibian papilla is developmentally derived from the neglected papilla [Fritzsch and Wake, 1988]. Finally, jawed vertebrates have evolved a third semicircular canal and an associated crista organ, which allows them to detect horizontal angular acceleration selectively [Lewis et al., 1985; Fritzsch et al., 2001]. In contrast, lampreys and hagfish must compute this information based on stimulation of one or both vertical canals. Ear evolution can thus be

characterized by progressive segregation and specialization of sensory epithelia embedded in an ever more complex threedimensional network of tubes and recesses, within which is embedded the more ancient and evolutionarily conserved mechanosensory module. Understanding how sensory and nonsensory components interact in evolution to result in a sensory epithelium, properly placed in the labyrinth of ducts and recesses and covered with the acellular structure appropriate for specific stimu- 
lus acquisition, is perhaps the biggest challenge in understanding ear evolution.

During vertebrate development, the progressive alteration in form, as well as the progressive segregation of sensory epithelia to be located appropriately for stimulus acquisition, appears to recapitulate ear evolution exactly [Fritzsch et al., 1998], an observation made by 19th century embryologists [Norris, 1892; Sarasin and Sarasin, 1892] and more recently confirmed by researchers using histology and molecular markers in amphibians and mammals [Fritzsch and Wake, 1988; Morsli et al., 1998; Farinas et al., 2001; Fritzsch et al., 2002]. In both evolution and development of the ear, the only constant feature is the sensory epithelia, composed of hair cells, as well as the pattern of their innervation [Fritzsch and Beisel, 2001; Fritzsch et al., 2002]. Throughout the dramatic morphological alterations of the ear, craniate hair cells show only limited variation and can be easily recognized by their distinctive feature, i.e., the apical 'staircase' of stereocilia, which enables all vertebrate ears to detect mechanical stimulation in a directionally-specific way [Lewis et al., 1985]. At least during development, all hair cells reveal an asymmetrical apical specialization, composed of a kinocilium and an organ-pipe like arrangement of stereocilia [Lim and Rueda, 1992; Strassmaier and Gillespie, 2002]. Several non-vertebrate species have somewhat similar apical specializations [Arkett et al., 1988; Jorgensen, 1989; Budelmann, 1992; Burighel et al., 2003; Mackie and Singla, 2003]. Tip links appear to represent an exclusively vertebrate specialization, with an unknown molecular base [Strassmaier and Gillespie, 2002]. Given the overall morphological similarities among ears, and the possibility that an as yet unknown mechanosensory transducer channel might be identical in many mechanosensory organs [Walker et al., 2000; Fritzsch and Beisel, 2001; Caldwell and Eberl, 2002; Kim et al., 2003], it is reasonable to argue that the evolution of the ear needs to be understood first and foremost as an evolution of hair cells, followed by increases in numbers of hair cells to form large epithelia, positioned to detect specific mechanical qualities of the stimuli that reach the ear. A second, closely associated aspect is the evolution of the sensory neurons connecting hair cells to the brainstem, a feature showed by vertebrates and certain non-vertebrate animals. We emphasize this aspect here, as sensory neurons are involved in conducting specific information, once it is detected, to the brain for processing [Maklad and Fritzsch, 2003].

In this review we will concentrate on the evolution of hair cells and sensory neurons, as these are the basic ele- ments from the mechanosensory module on which selection acts to provide for detection of different qualities of sound and for selective information processing. The morphological alterations briefly outlined above have been addressed in several reviews [Lewis et al., 1985; Fritzsch et al., 1998; Maklad and Fritzsch, 2003] and will not be detailed here, with two exceptions: the evolution of the horizontal canal [Morsli et al., 1999; Fritzsch et al., 2001] and the evolution of the sarcopterygian basilar papilla [Fritzsch, 1987, 2003].

\section{Cellular Evolution of the Ear: The Ancestry of Mechanosensory Cells}

The original proposal that all mechanosensory cells might be related [Jorgensen, 1989] was recently expanded. We proposed that the evolution of mechanosensory transducers is conserved molecularly across phyla and thus establishes in development a transcription factor link that selectively expresses the still unknown mechanosensory transducer channels in those cells [Fritzsch and Beisel, 2001]. In addition, other molecular entities will also be required for the transducer cells to maintain the biophysical function of the mechanosensory module. This hypothesis builds on the novel finding of a molecularly conserved gene that is essential for sensory cell formation across phyla, the fly atonal gene and its mammalian orthologue Atoh1 [Bermingham et al., 1999; Ben-Arie et al., 2000; Fritzsch et al., 2000; Wang et al., 2002]. The theory also assumes that the evolution of mechanosensory transducer cells predates the evolution of a morphologically distinct vertebrate ear. In contrast to the acousticolateralis hypothesis [van Bergeijk, 1966; Wever, 1974; Northcutt, 1980], this hypothesis does not require an assumption of the prior evolution of a lateral line system to generate a 'simple-to-complex' progression. It thus circumvents some of the problems associated with the acoustico-lateralis hypothesis, while maintaining the basic idea that evolution of mechanosensory transducers and their developmental molecular basis predates ear morphogenesis. It needs to be stressed that this hypothesis does not distinguish between the notion of an ear first, followed by segregation of hair cells and sensory neurons, or the notion of a segregation of hair cells and sensory neurons preceding an ear. In other words, it is possible that the original chordate ear was composed of mechanosensory cells with axons similar to the ciliated sensory neurons in Caenorhabditis and Drosophila [Jorgensen, 1989]. 
Although the mammalian mechanical-gated transduction channel has yet to be identified, non-selective cation channels are potential candidates and represent members of the TRP, TMC, or $\mathrm{BNaC}$ (touch receptor associated channels) gene families [Garcia-Anoveros et al., 2001; Welsh et al., 2002]. The involvement of many of the TRP receptor family members in sensory epithelium, along with functional diversification of the TRP channels [Hekimi and Guarente, 2003; Liedtke and Friedman, 2003; Mutai and Heller, 2003], implies that the differential distribution of these receptors is facilitated via divergent cell differentiation. It is very likely that this differential expression is mediated by various bHLH genes assigning the appropriate cellular differentiation required for the specific function of the associated receptor(s). It remains to be shown how, directly or indirectly, TRPV [Keresztes et al., 2003a] or other channels, such as BNaC [Welsh et al., 2002] and TMC [Keresztes et al., 2003a], that are possibly involved in various sensory stimuli acquisition, depend on bHLH genes for their expression. Interestingly enough, the worm Caenorhabditis elegans has only a single bHLH gene of the ATO group: LIN-32 [Hassan and Bellen, 2000]. This gene is important for sensory ray development in the tail of worms, as LIN-32 null mutants are touch insensitive to only that area of the body [Zhao and Emmons, 1995]. In contrast to the anterior touch-sensitive and chemosensitive organs, which use TRP family members, the posterior touch-sensitive organs use sodium channels of the $\mathrm{ENaC} / \mathrm{BNaC}$ family [Liedtke et al., 2003]. These data in C. elegans suggest that common chemo/ osmo/mechanosensors exist and that the atonal paralogue Lin-32 regulates BNaC-like channels for mechanosensation. Yeast two hybrid studies and developmental network analysis, such as those recently conducted for a set of proteins in flies [Giot et al., 2003] and the gastrulation of sea urchins [Davidson et al., 2002], are needed to establish causality between bHLH genes and specific channel expression in the evolution of the ear's mechanosensory component.

In this context it is interesting to note that vertebrates have evolved two atonal orthologues, Atoh1 and Atoh5 [Hassan and Bellen, 2000; Sun et al., 2003], with nonoverlapping function. It appears that Atoh5 and atonal are essential for retinal ganglion cell development and photoreceptors, respectively [Wang et al., 2001; Sun et al., 2003]. Atoh5 is important in retina ganglion cell development and appears to govern the development of a unique photoreceptor dedicated to circadian rhythm [Hannibal et al., 2002]. This gene duplication occurred in vertebrate ancestors and may provide an important additional regu- lator element that establishes the hair cell TMC channels and G-protein related functions [Keresztes et al., 2003a, b]. Possibly Atoh1 and Atoh5 have acquired distinct functions in the developing ear, governing the cell fate acquisition of inner ear ganglion cells and hair cells, respectively. Unfortunately, although Math5 is reportedly expressed in ear development [CM Chen, personal communication], no analysis of the ear phenotype has been conducted in Atoh5 null mutant mice [Sun et al., 2003]. Consistent with recent data suggesting that mammalian Atoh genes might have lost some of their proneural function [Bertrand et al., 2002], frog and chicken Atoh5 are able to rescue fly eye development, but mammalian Atoh5 is not [Sun et al., 2003]. It is likely that Atoh function is not fully conserved across vertebrates and that mammalian Atoh genes could require some component of a mammalian-specific environment to realize their potential. It is therefore essential to analyze the expression and function of both Atoh1 and Atoh5 in non-mammalian vertebrates, as these genes in non-mammals have apparently retained more of the proneuronal signaling capacity of the ancestral atonal-like gene. It is also important to demonstrate that the Atoh $1 / 5$ divergence evolved after the evolution of neurons connecting the ear to the brain in craniate ancestors.

\section{Evolutionary Origin of the Vertebrate Inner Ear Sensory Neurons}

One novel feature of the vertebrate ear, compared to most non-vertebrate mechanosensory cells, is the existence of sensory neurons connecting the hair cells (which have no axons) to the brain. The widespread presence of mechano- and chemosensory cells, which send their own axons to the central nervous system, among triploblastic and diploblastic organisms suggests that such sensory cells (also referred to as primary sensory cells) are primitive features of metazoan animals. In contrast, the existence of cells specialized for sensory transduction but having no axons (also referred to as secondary sensory cells), combined with the existence of 'sensory' neurons that conduct the information detected by these secondary sensory cells to the brain, is considered here a derived feature (figs. 2, 3). Available evidence suggests that the evolution of this derived feature, i.e., secondary sensory cells combined with conducting neurons, likely occurred independently in several animal phyla [Jorgensen, 1989; Budelmann, 1992; Mackie and Singla, 2003]. Sensory neurons, however, may be primitive even for vertebrates, as they might 


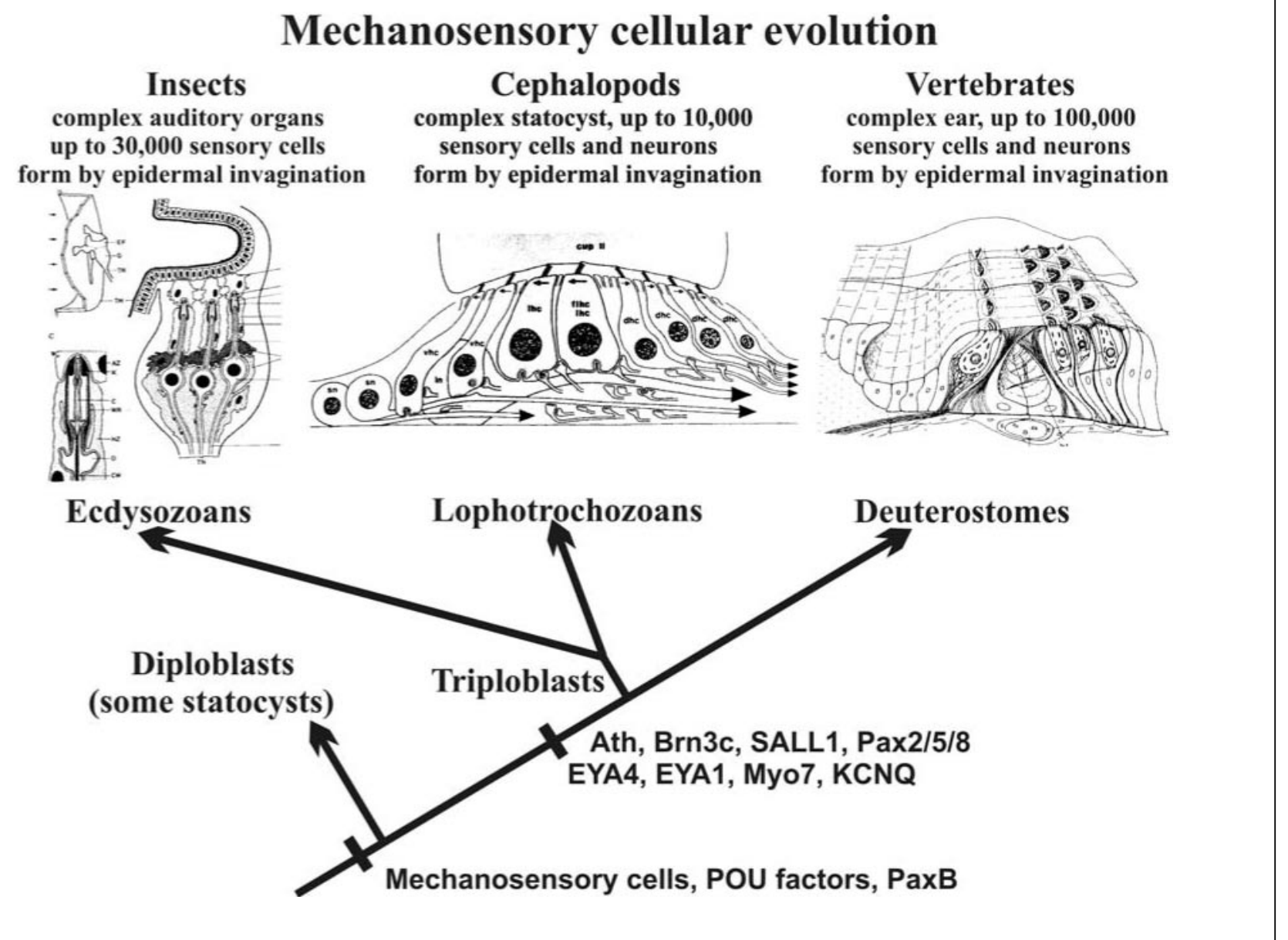

Fig. 2. The independent formation of morphologically distinct sensory organs in the three clades of triploblastic animals is contrasted with the evolution of a molecular network involved in mechanosensory cell formation, which might have already evolved in diploblastic animals. Note also that organs specialized for gravity perception evolved, apparently independently, in diploblastic organisms, sup- porting the idea of the ancestry of mechanosensory transduction. Note that numerous genes known to affect auditory sensation are present in both ecdysozoans and chordates and therefore likely evolved in the common triploblastic ancestor. [Modified from Fritzsch and Beisel, 2003; Kozmik et al., 2003; O'Brien and Degnan, 2003]. See table 1 for details regarding the genes. have arisen in the common ancestor of vertebrates and Ascidians, an outgroup of vertebrates [Burighel et al., 2003].

Irrespective of the actual evolutionary history, logic mandates that such diversification from a single precursor pool requires alternative contextual utilization, alternative combinatory forms, alternative splice forms, and/or multiplication of cell fates assigning genes to direct divergent cellular differentiation. Obviously, insect mechanosensory cells require a single bHLH gene to form: atonal (ato) for scolopidial organs and achaete (ac) and/or scute (sc) for bristles on the cuticula [Hassan and Bellen, 2000;
Bertrand et al., 2002]. It is likely, therefore, that sensory neurons arose in phylogeny only after ancestral bHLH gene duplication allowed for separate assignment of cell fates and/or after a novel bHLH gene was recruited into the precursor population (fig. 3). In mammals and Zebrafish the cell fate assignment is via neurogenin 1 (neurog1; for sensory neurons) and Atoh1/Math 1 (for hair cells), as shown by null mutations as well as some transgenic misexpression [Ma et al., 1998, 2000; Bermingham et al., 1999; Andermann et al., 2002; Wang et al., 2002]. Misexpression data for the insect ato gene and the vertebrate Atoh1 gene show mutual rescue in both phyla [Ben-Arie et 


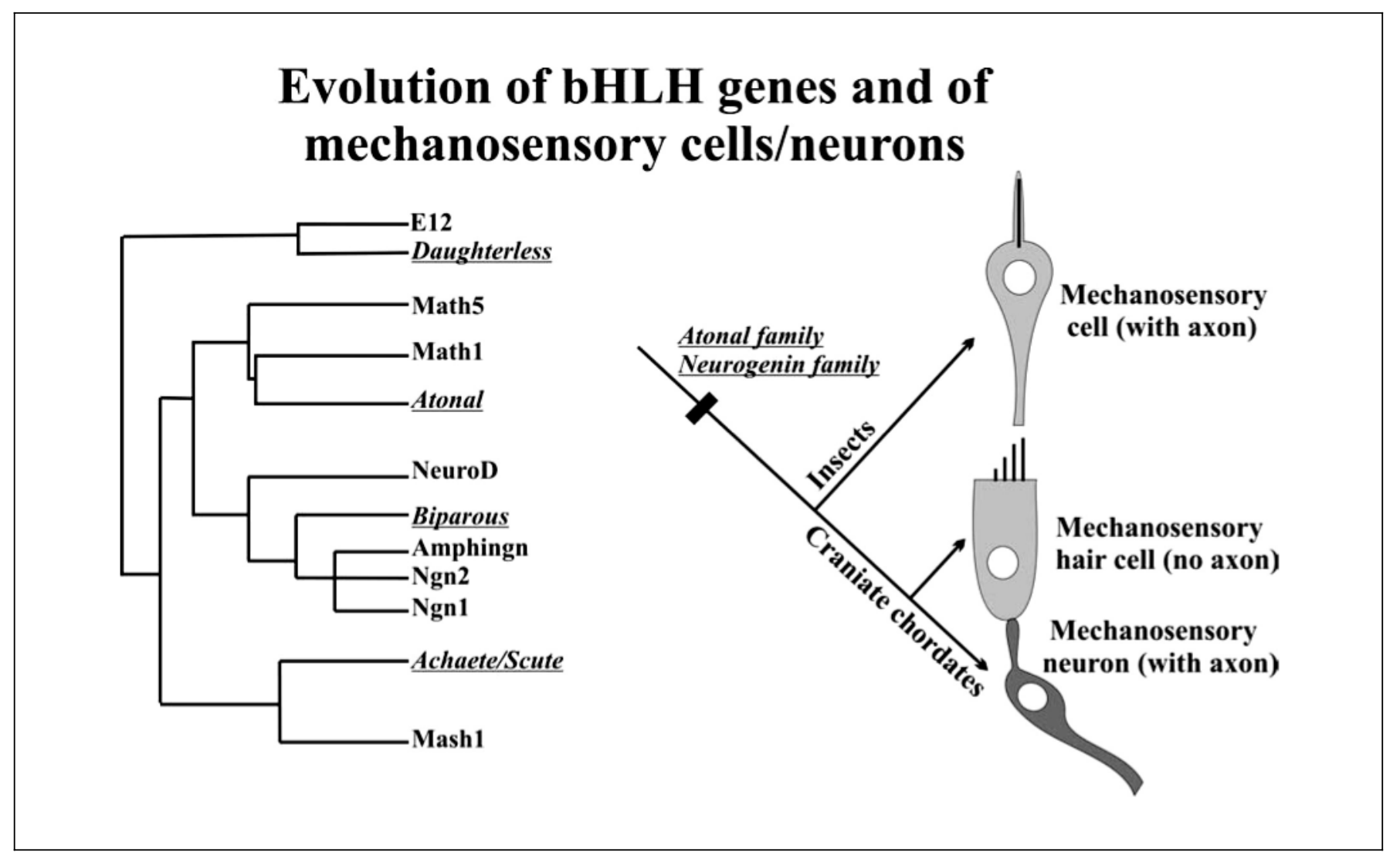

Fig. 3. The evolution of bHLH genes involved in mechanosensory cell formation and the implications of this molecular evolution for the evolution of different mechanosensory morphologies in insects and craniates are shown. Note that insects and craniates have paralogous members of each of the four families. However, although craniates have both neurogenin and atonal family members playing a role in the ear (ngn1 governs sensory neuron formation, Atoh1/ Math1 that of hair cells), insects have only one bHLH gene member involved which governs the formation of the mechanosensory cell (with axon). The distribution of insect and craniate genes of the bHLH family suggests that bHLH multiplication predated the evolution of two distinct cell types in the craniate ear, each one associated with a conserved (atonal) and a novel (ngn1) gene associated with mechanosensory development. Insect genes are in italics. [Modified from Fritzsch et al., 2000; Bertrand et al., 2002]. al., 2000; Wang et al., 2002], suggesting that cell fate assignment via ato/Atoh1 has been evolutionarily conserved for certain mechanosensory cells, whereas neurogenin 1 (Neurog1) was recruited for the development of sensory neurons in vertebrates. It appears that the fly orthologue for neurogenin, target of Poxn (tap; previously designated as biparous), co-exists with ato in the development of certain insect chemosensory cells, whereas in the lancelet, neurogenins are not utilized for PNS development [Holland et al., 2000]. Interestingly, Neurog 1 plays a major role in mammalian olfactory development, as it is important for olfactory precursor proliferation [Wu et al., 2003].
Unfortunately, we do not know the functional role of ato/Atoh orthologues, or that of neurogenin orthologues, in the development of non-mammalian vertebrates or in other animals that have distinct mechanosensory cells and conducting neurons [Budelmann, 1992; Burighel et al., 2003]. Paralogues of several bHLH genes exist in ascidians [Dehal et al., 2002] and amphioxus [Holland et al., 2000], and their function needs to be assessed with the use of knock-down techniques, such as siRNA or morpholinos [Yamada et al., 2003], as well as knockins of mammalian and fly orthologues.

In summary, we propose that the transformation of pro-neuronal clusters that give rise to ciliated sensory neurons in insects, into clusters that give rise to both hair cells 
and sensory neurons in vertebrates, could have been accomplished by the recruitment of an existing neurogenin gene to govern the divergent sensory neuron development. This implies that molecular divergence predates cellular divergence (fig. 3). We further propose that another round of division of sensory neuron precursor cells gave rise to hair cells (retaining Atoh1) and sensory neurons (recruiting Neurog1). Such a scenario suggests that both hair cells and sensory neurons are derived from ciliated mechanosensory cells such as those found in insect scolopidial organs. It also suggests a clonal relationship between vertebrate hair cells and sensory neurons [Fritzsch et al., 2000; Hassan and Bellen, 2000], consistent with data showing dramatic reduction in hair cell formation in Neurog1 null mutant mice [Ma et al., 2000]. Recent evidence for this switch suggests that the molecular basis is due to the Tbx 1 gene. More sensory neurons are generated in Tbx1 null mutant mice and fewer sensory neurons form in TBX1 overexpressors [Raft et al., 2004]. Although the available data suggest that there might be a respective upand down-regulation of hair cell formation, more quantitative data are needed to fully support this interesting possibility.

Evolutionary history leaves little doubt that the origin of sensory cells with axons predates that of sensory neurons and sensory cells without axons. Therefore, the very early formation of sensory neurons in inner ear development, prior to that of hair cells [Ma et al., 1998; Bermingham et al., 1999] suggests a significant reorganization of developmental pathways to implement this evolutionary novelty. In fact, existing data suggest that Neurog1 is expressed at least one day prior to Atoh1 in mice [Ma et al., 1998; Zine et al., 2001]. In Zebrafish, weak expression of atoh1 precedes that of neurog1 by several hours, but strong expression of atoh1 occurs about one hour after neurog1 expression is upregulated [Riley, 2003]. Together with the apparent dependency of some sensory hair cell formation on the expression of Neurog 1 [Ma et al., 2000], this suggests both a heterochronic shift as well as functional alteration of the signaling capacity of Neurog 1 and Atoh1 in mammals. These data thus suggest that the evolutionary addition of a novel cell fate happened through temporal alteration of cell fates, much like the sequential cell fate assignment of neurons and glia cells in the developing brain from one precursor [Bertrand et al., 2002]. Inoue and colleagues [2001] have shown that the bHLH gene Atoh6 is involved in glia cell formation. Further research is needed to show whether this functional and temporal alteration is specific to mammals and related to the reduction in proneural signaling of the aton- al genes [Hassan and Bellen, 2000; Bertrand et al., 2002; Sun et al., 2003] , whether it is primitive for vertebrates, irrespective of the alteration in Atoh signaling, and whether Neurog1 null mutation/knock down with morpholinos will affect hair cell formation in other craniates.

\section{Evolutionary Origin of the Vertebrate Ear}

It is apparent from the evolutionary origin of sensory neurons delineated above that this aspect of ear evolution is characterized by a heterochronic developmental alteration, resulting in an evolutionary 'late-comer' as the first distinct cell line to develop in the mammalian ear [Ma et al., 1998; Hatini et al., 1999]. This heterochronic reorganization of ear development is embedded in the concentration of neuronal potential of the entire ectoderm, as found in acorn worms and in diploblastic organisms [Lowe et al., 2003], into discrete areas dedicated to neuron and sensory cell formation, such as the neural tube and ears of vertebrates. Both neural tube formation and placodal formation need to be regarded as distinct embryological adaptations dedicated to increasing the local formation and proliferation of hair cells and sensory neurons, at the expense of neuronal formation in the remaining ectoderm, which is relegated to skin formation through the upregulation of Bmp4. Moreover, placodal formation is not unique to vertebrates and appears in all lineages in which a discrete increase in proliferation generates large sensory organs (fig. 2). For example, the expansion of the cell lines giving rise to scolopidial organs, which become Johnston's organs in the dipteran antenna, is through a placodal-like thickening that undergoes invagination, much like the vertebrate ear [Yager, 1999]. Unfortunately, the ontogeny of complex statocysts of diploblastic organisms, such as ctenophorans [Markl, 1974] or cnidarians [Kozmik et al., 2003], is not known. Such information is necessary to exclude the possibility that the apparent multiple evolution of placodal thickenings in triploplastic organisms is not a derived feature that evolved only once in the triploblastic ancestor. If this were the case, the lack of complex organs might represent a case of regressive evolution, an important feature in vertebrate ear and vertebrate lateral line evolution [Fritzsch, 1988; Schlosser et al., 1999].

Likewise, genes associated with the enhanced proliferation necessary to establish a placodal thickening, such as fibroblast growth factor and forkhead genes, are known only in vertebrates [Hatini et al., 1999; Pauley et al., 2003; Solomon et al., 2003; Wright and Mansour, 2003], not in insects, cephalopods or diploblastic organisms. It would 
be important to establish whether in the latter phyla the antineuronal action of bone morphogenetic protein/decapentaplegic is overcome through upregulation of some other set of genes that establish and maintain neuronal precursor proliferation, as do Fgf's, Forkheads, Eya/Six/ Dachs complex, Dlx, Tbx, Zic and other associated genes [Fritzsch and Beisel, 2003].

Based on this outgroup comparison it seems likely, but not conclusive, that evolution of the ear was intimately related to the formation of an ear placode. However, it is entirely possible that evolution of the ear, as a morphological entity to detect gravity, analogous to the many statocysts found in various phyla, might have predated the evolution of an ear placode. If so, the formation of an ear placode would be related to the specific enlargement of the ear anlage, much like the ectodermal anlage increases in size in hearing organ formation in insects [Yager, 1999]. Without specifying why placodes may have evolved as an embryonic adaptation to achieve this increase in a precursor population, it has been proposed that placodes undergo a stepwise refinement from a general placode system to a more specialized lateral line and ear placode system [Noramly and Grainger, 2002; Streit, 2002]. However, it is still unclear whether a common developmental program exists for the various sensory placodes found in the vertebrate head [Groves and BronnerFraser, 2000; Begbie and Graham, 2001; Brown et al., 2003]. It also remains unclear how the few genes known thus far to be involved in setting the stage for ear placode induction relate to the formation of the neurosensory and non-sensory aspects of the ear and the lateral line.

Some heterochronic uncoupling of lateral line and ear development, as well as the complete loss of lateral line placodes in terrestrial vertebrates [Fritzsch, 1999; Schlosser, 2002], suggests a degree of morphogenetic independence of the lateral line development and ear development. Moreover, the basic molecular patterning underlying placodal formation is also used in the formation of craniate novelties, such as teeth, glands and hair [Pispa and Thesleff, 2003], suggesting that the mechanism to transform discrete areas of skin, once evolved, has been put to differential use in both spatially and temporally distinct specializations of the ectoderm. In the light of these data, it appears highly unwise to use placodes as an indicator of homology in the context of early ear induction, as they are clearly embryological adaptations with a varied history of evolution. Likewise, cephalopods are the only invertebrates that have evolved both an ear-like system and a lateral-line-like system, again with an unknown developmental relationship. Still, in the case of cephalo- pods, it is clear that a statocyst evolved prior to the lateralline-like system [Budelmann and Bleckmann, 1988], as many mollusks posses statocysts [O'Brien and Degnan, 2003]. Further studies in vertebrates are needed to establish whether there is an inductive interaction of lateral line placodes and otic placodes, or whether they share some, but not all, aspects of their molecular basis related to the induction of hair cells and sensory neurons. Additional characterization of the spatiotemporal expression patterns of other genes is required to determine when the placodes switch from an ectodermal thickening process to initiation and transformation into a developing mechanosensory module or organ.

The next evolutionary problem was the expansion of the prototypic mechanosensory module into a functionally unified endorgan. Formation of complex organs, dedicated to the perception of specific sensory stimuli, from aggregates of sensory cells is known in both diploblastic and triploblastic organisms. Such cellular arrays can consist of several thousand sensory cells (fig. 2). Little is known about the specific molecular governance of the development of such multicellular sensory arrays in nonvertebrate animals, including the formation of the auditory systems of insects [Yager, 1999; Caldwell and Eberl, 2002]. Numerous genes (table 1) have been identified and established to act similarly in insect and vertebrate auditory systems and, if mutated, cause deafness [Fritzsch et al., 2000; Caldwell and Eberl, 2002]. Many genes cause syndromic deafness across phyla, such as the zinc-finger gene-mediated Townes-Brocks-Syndrome [SALL1; Dong et al., 2003; Kiefer et al., 2003] or the Usher syndrome 1B, DFNA11, and DFNB2 [MYO7A; Weil et al., 1996; Friedman et al., 1999; Caldwell and Eberl, 2002]. Other genes cause hearing deficits in both mammals and insects, suggesting highly conserved cellular proteins involved in hearing across phyla. For example, recent data have shown that the mammalian orthologue of the fly gene 'senseless' (Gfi1) causes hair cell loss in mutant mice [Wallis et al., 2003]. Indeed, in insects, senseless (sens) can act as a true proneural gene that determines the prosensory patch [Jafar-Nejad et al., 2003]. Another gene of the zinc-finger transcription family, Gata3, is involved in hearing-related disorders in humans [Van Esch and Devriendt, 2001], and Gata3 null mutant mice show agenesis of the ear [Karis et al., 2001]. Unfortunately, the role of the Gata3 orthologue, pannier, was investigated only in cuticular sense organs [Sato and Saigo, 2000], not in chordotonal organs.

Beyond these conserved genes, other developmental transcription factors are unique for vertebrate ear devel- 
Table 1. Some Drosophila and human genes known to affect hearing or being important in ear development compared

\begin{tabular}{llll}
\hline Disease & Human gene & Drosophila orthologue & Function \\
\hline DFNA1 & DAIPH1 & diaphanous & actin binding \\
DFNA2 & KCNQ4 & CG12215 & Vg K $^{+}$channel \\
DFNA10 & EYA4 & clift & transcription factor \\
DFNA11 & MYO7A & crinkled & actin binding \\
DFNA13 & COL11A2 & Cg25C & structural \\
DFNA15 & POU4F3 (BRN3C) & Acj6 & transcription factor \\
DFNA17 & MYH9 & zip & motor protein \\
DFNB3 & MYO15 & CG2174 & motor protein \\
DFNB4 & SLC26A4 (PDS) & CG5485 & anion transporter \\
JLNS1 & KCNQ1 (KVLQT1) & CG12215 & Vg K channel \\
Branchio-oto-renal syndrome & EYA1 & clift & transcription factor \\
Di George syndrome & GATA3 & pannier & transcription factor \\
Alport & FACL4 & I(2)44DEa & 45\% \\
Townes-Brocks syndrome & SALL I & spalt & transcription factor \\
DFN3 & POU3F4 (BRN4) & ventral veins lacking & transcription factor \\
$?$ & ATH1 & atonal & hair cell differentiation \\
Nonimmune chronic idiopathic & & & \\
$\quad$ neutropenia of adults & GFI1 & senseless & hair cell survival \\
Renal-Coloboma syndrome & PAX2 & Dpax-2 (sparkling) & transcription factor \\
\hline
\end{tabular}

opment, as there is neither expression in the developing Johnston's organ nor orthologues in the Drosophila genome. For example, two Fgf genes, Fgf10 and Fgf3, are essential for ear morphogenesis in mammals [Alvarez et al., 2003; Pauley et al., 2003; Wright and Mansour, 2003]. In Drosophila, only a single fibroblast growth factor gene, branchless (bnl), exists, compared with the 22 orthologues found in mammals [Sutherland et al., 1996; Wright and Mansour, 2003]. However, this ligand is unlikely to be involved in Johnston's organ formation, as no effects are seen in the null mutation. Conclusive evidence is still needed to exclude the possibility that Fgf genes play some role for chordotonal organ formation in the fruit fly, such as regulating the proliferation that leads to formation of the placode-like precursor of the insect chordotonal organ [Yager, 1999]. Clearly, ectodermal differentiations, such as neurogenic placodes for hair, feathers, teeth and glands, share a number of developmental genes, suggesting an evolutionarily conserved developmental module [Pispa and Thesleff, 2003]. Alternatively, and consistent with long recognized significant structural differences, certain molecular differences in developmentally relevant transcription factors must exist between Drosophila and vertebrate 'ear' development, and Fgf involvement might be among those.

\section{Morphological Evolution of the Ear: The Case of the Horizontal Canal and the Cochlea}

Expansion of the number of endorgans represents the next logical stage in ear evolution [Fritzsch et al., 2002]. We will use the development of the horizontal canal and the cochlea as our paradigm for endorgan expansion and subsequent functional diversification. The craniate ear reveals two major morphological innovations: the evolution of the horizontal canal and the evolution of the sarcopterygian basilar papilla, which appears to become the mammalian cochlea (fig. 1). Recent progress suggests that the expression of the fly orthodenticle gene paralogue, Otx1, is directly involved in horizontal canal formation [Morsli et al., 1999]. This canal is reportedly absent in otherwise relatively normal Otx1 mutant ears [Cantos et al., 2000]. Closer examination reveals that at least parts of the horizontal crista form but either remain attached to the utricle or form a small sensory patch not recognized in the control littermate's ear [Fritzsch et al., 2001]. Comparison with the ears of lampreys suggests that the pattern of innervation of a sensory patch in lampreys, called the dorsal macula, resembles that of the displaced sensory patches found in Otx1 null mutant mice. These data support the suggestion that the evolution of sensory patches, and the evolution of specific canals to provide novel 
input, is a two-step process, with the neurosensory specialization predating the morphological alterations. Our preliminary data suggest that another gene, the forkhead factor BF1 (Foxg1), might not only be expressed in all neurosensory components of the developing mammalian ear [Hatini et al., 1999] but also could be essential for the formation of the horizontal crista [unpublished observations].

Much less is known for vestibular functional deficits in genes associated with non-syndromic deafness, despite the evidence that all genes listed in table 1 are also expressed in the vestibular system. Sound reception in insects evolved at least 19 times out of chordotonal organs [Yager, 1999]. Likewise, sound reception is achieved with different modifications of existing or unique sensory epithelia in vertebrates [Fritzsch, 1999]. It therefore cannot be ruled out that hearing-related effects of these genes are independently derived in Drosophila and mammals. So, similarities found at a molecular level might reflect only synapomorphies between vestibular and proprioreceptive functions, which are already found in the common triploblastic ancestor of chordates and ecdysozoans. Essentially, mechanosensory cell formation would predate the split of the three triploblastic lineages, such that in diploblastic organisms these cells could already have evolved the capacity to be transformed into a sound receiver (fig. 2).

This theme of neurosensory specialization predating morphological specialization is particularly apparent in the evolution of the sarcopterygian basilar papilla into the mammalian cochlea. Based on pattern of innervation, topology, and histological specialization, the basilar papilla in Latimeria, many amphibians, and most amniotes, resembles the cochlea of eutherian mammals. Aside from the potential function of these organs in detecting sound pressure, the morphological similarities are most easily explained by assuming a single evolution of this end organ, with subsequent modification during terrestrial evolution for the purpose of detecting airborne sound pressures [Fritzsch, 1992, 2003]. Among those modifications was the loss of the lagena near the apex of the basilar papilla, a structure present in all tetrapods, except for some species of amphibians and all marsupial and eutherian mammals [Jorgensen and Locket, 1995]. It is unclear how the loss of the lagena relates to the progressive elongation and coiling of the mammalian cochlea and its enhancement for high frequency detection. At the very least, however, this regressive event shows that in several vertebrate lineages there is a potential and unexplored molecular coupling between loss of certain end-organs in the ear and the evolution of others [Fritzsch and Wake, 1988].
Recent developmental data support the idea that the cochlea is derived developmentally from the saccule [Morsli et al., 1998; Farinas et al., 2001; Fritzsch et al., 2002], but these data are not detailed enough to suggest the molecular steps involved in transforming a gravistatic sensor into a sound pressure receiver. Likewise, some molecular alterations in the acellular statoconia of statocyts and the cochlear acellular tectorial membrane are becoming apparent, but the molecular basis for these changes has not been elucidated [Goodyear and Richardson, 2002].

\section{Evolution of Eyes and Ears: Molecular Evidence for Common Molecular Developmental Aspects}

We will explore the idea that a common evolutionary ancestor might have possessed the basic sensory structures that eventually developed into sensory organs. If this is the case, then conserved rudimentary elements should exist in gene networks and transcription regulatory elements, as well as in some of their associated structural and functional components. In this context, several lines of evidence suggest even deeper similarities in the development of eyes and ears across phyla, based on certain transcription factors, their sequence identity, and their expression patterns (see table 2). Evidence for conserved cisregulatory element(s) have been identified in Drosophila, which are shared by a number of segment-specific organs, including compound eyes, the Johnston's auditory organ, and the chordotonal stretch receptors [Niwa et al., 2004]. Data for developmental gene networks show that an important gene for eye development, Pax6, and an important gene for ear development, Pax2, may both be derived from a common ancestor that is expressed in both the adjacent statocyst and eye in free-swimming jellyfish [Kozmik et al., 2003]. The function of this ancestral PaxB gene in jellyfish and vertebrate eyes appears to be the activation of lens crystallin genes. PaxB can rescue Pax6 (eyeless) function in the fly. The fly orthologue of the Pax $2 / 5 / 8$ genes, Dpax-2 or sparkling, is expressed in numerous fly mechanoreceptors and is important for their formation, including the formation of chordotonal organs [Kavaler et al., 1999]. In the jellyfish, PaxB might be involved in the formation of statoconia, which have crystallins similar to those of the lens of the eye [Piatigorsky, 2003]. Whether otoconia, which consist of a complex mixture of various proteins, are affected in Pax2 null mutants [Favor et al., 1996; Torres and Giraldez, 1998] remains unclear. Whether the Pax pathway similarities suggest a distant 
Table 2. Comparison of eye and ear genes

\begin{tabular}{llll}
\hline $\begin{array}{l}\text { Mammalian gene } \\
\text { (expression) }\end{array}$ & $\begin{array}{l}\text { Drosophila gene } \\
\text { (expression) }\end{array}$ & $\begin{array}{l}\text { Mollusc gene } \\
\text { (expression) }\end{array}$ & $\begin{array}{l}\text { Jellyfish gene } \\
\text { (expression) }\end{array}$ \\
\hline $\begin{array}{l}\text { Pax 6 } \\
\text { (eye) }\end{array}$ & $\begin{array}{l}\text { Eyeless } \\
\text { (eye) }\end{array}$ & $?$ & $\begin{array}{l}\text { PaxB } \\
\text { (eye, statocyst) }\end{array}$ \\
\hline $\begin{array}{l}\text { Pax 2 (5/8) } \\
\text { (eye/ear) }\end{array}$ & $\begin{array}{l}\text { Dpax-2 (sparkling) } \\
\text { (chordotonal organs) }\end{array}$ & $\begin{array}{l}\text { Pax 2/5/8 } \\
\text { (statocyst, } \\
\text { chemosensors) }\end{array}$ & $\begin{array}{l}\text { PaxB } \\
\text { (eye, statocyst) }\end{array}$ \\
\hline $\begin{array}{l}\text { Pou4f3 (Brn3c) } \\
\text { (ear) }\end{array}$ & $\begin{array}{l}\text { Acj6 } \\
\text { (chordotonal organs) }\end{array}$ & $\begin{array}{l}\text { Pou-IV } \\
\text { (statocyst) }\end{array}$ & $?$ \\
\hline $\begin{array}{l}\text { Atoh1 } \\
\text { (ear) }\end{array}$ & $\begin{array}{l}\text { Atonal } \\
\text { (eye, Johnston's organ) }\end{array}$ & $?$ & $?$ \\
\hline $\begin{array}{l}\text { Atoh5 } \\
\text { (eye, ear?) }\end{array}$ & $\begin{array}{l}\text { Atonal } \\
\text { (eye, Johnston's organ) }\end{array}$ & $?$ & $?$ \\
\hline $\begin{array}{l}\text { Eya 1+4 } \\
\text { (eye, ear) }\end{array}$ & $\begin{array}{l}\text { Clift } \\
\text { (eye) }\end{array}$ & $?$ & $?$ \\
\hline $\begin{array}{l}\text { USH1B (Myo7a) } \\
\text { (eye, ear) }\end{array}$ & $\begin{array}{l}\text { Crinkled } \\
\text { (Johnston's organ) }\end{array}$ & $?$ & $?$ \\
\hline $\begin{array}{l}\text { USH1D (Cdh23) } \\
\text { (eye, ear) }\end{array}$ & $\begin{array}{l}\text { Fat } \\
\text { (eye, Johnston's organ) }\end{array}$ & $?$ & $?$ \\
\hline $\begin{array}{l}\text { USH1C (Harmonin) } \\
\text { (eye, ear) }\end{array}$ & $\begin{array}{l}\text { CG5921 } \\
?\end{array}$ & $?$ & $?$ \\
\hline
\end{tabular}

ancestry of certain eye- and ear-related developmental pathways, or whether they reflect the parallel use of a developmental model much like the Eya/Six/Dach module in ear, eye and kidney development [Xu et al., 1999a, b; Zheng et al., 2003], also remains to be seen. However, recent data suggest that $\mathrm{Pax} 2$ is also involved in statocyst formation in mollusks [O'Brien and Degnan, 2003]. Also, the Pax2/5/8 gene has even been found in the sponge genome and could thus have evolved prior to the formation of diploblastic organisms. Indeed, free-swimming sponge larvae have both mechanosensory and photosensory capabilities, without having formed obvious sense organs or even sensory cells [O'Brien and Degnan, 2003]. The molecular nature of these mechanosensory and photosensory capacities needs to be investigated before further conclusions can be drawn.

Clearly, the linkage between common eye and ear disorders found in Usher syndromes would be compatible with either scenario. Moreover, the available data suggest that Math1/atonal are interchangeable to mediate hair cell/chordotonal organ formation as well as ganglion cell/ R8 photoreceptor differentiation [Wang et al., 2002; Sun et al., 2003]. It remains to be seen whether PaxB in jelly- fish is involved in upregulation of atonal-like bHLH genes and, if so, how much of this upregulation relates to conserved bHLH genes used in both eye and ear cell fate determination. It would be very interesting to determine whether the multiplication and diversification of $\mathrm{Pax}$ genes in triploblastic organisms, relative to those in diploblastic organisms, is accompanied by an equal multiplication and diversification of atonal-like bHLH genes that have diversified to mediate mechanosensory and photosensory stimulus acquisition via different transduction channels and mechanisms.

The genes involved in Usher's Syndrome are uniquely critical for retinal and cochlear cell function although they are found in many other tissues and cell types. Many of these genes are involved in an interactive network of proteins required for stereocilia homeostasis [Boeda et al., 2002]. This protein network, which cooperates to shape the sensory hair cell bundle, includes usherin (USH2A), myosin VIIa (MYO7A), cadherin 23 (CDH23), protocadherin 15 (PCDH15), harmonin (USH1C), clarin 1 (USH3A), and SANS (USH1G). Another unique group of proteins are the extracellular, cell-surface-associated filaments associated with the stereocilia, designated as tip- 


\section{Crucial nodes in mechanosensory evolution}

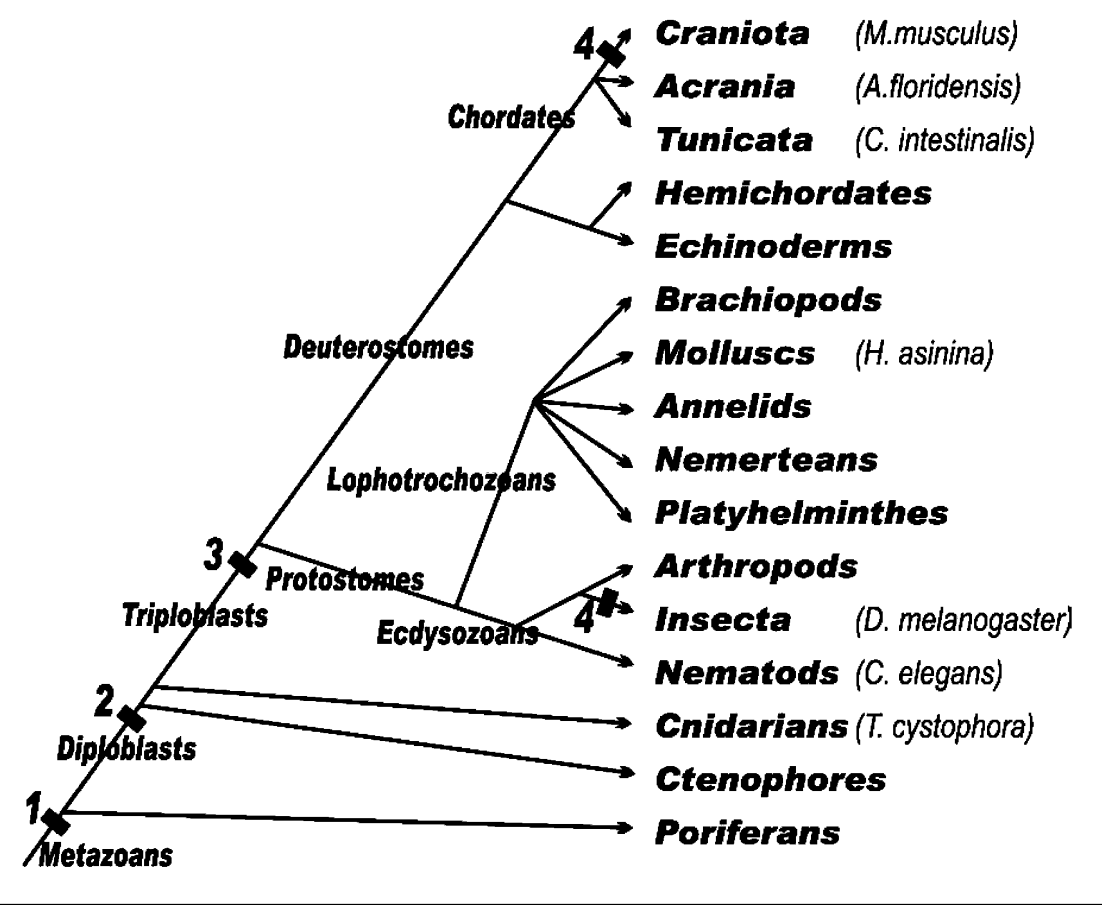

Fig. 4. The distribution of some of the species and the taxa they belong to are displayed to provide the context of our current understanding of mechanosensation in metazoan evolution. Note that $1,2,3$, and 4 indicate steps at which certain molecular, cellular and histological specializations must have existed, and these specializations thus represent shared derived characters of the organisms constituting the crown groups. (1) A mechanosensory channel must have already existed in unicellular organisms and is thus considered ancestral to metazoans. Data on poriferans showing the existence of Pax and Pou domain factors support this notion. (2) Diploblasts share mechanosensory channels that can be experimentally exchanged between $C$. elegans and $M$. musculus. These channels belong to the $\mathrm{TRP}, \mathrm{ENaC} / \mathrm{BNac}$ or TMC channels and are in cells specialized for mechanosensation. Cells containing these channels may require Pou domain factors for their differentiation and Pax for their assembly into larger organs. (3) bHLH genes of the atonal family are essential for mechanosensory cell/hair cell differentiation. Other genes such as senseless, pannier, decapentaplegic, Eya are involved in organ formation and are also conserved across phyla, as they are found in both insects and chordates. The presence of a single bHLH gene in $C$. elegans might be a secondary reduction. (4) Auditory organs evolved independently in chordates and insects several times, always modifying the mechanosensory system used in gravity and chordotonal sensation in those two lineages, respectively. [Modified from Fritzsch and Beisel, 2003; Kozmik et al., 2003; O'Brien and Degnan, 2003]. and ankle-links [Goodyear and Richardson, 1999, 2002]. Data from Goodyear and Richardson [1999, 2002] have shown that these filaments are also present in the ciliary calyx of photoreceptors. It would be important to determine if similar structures are present in the ciliated neurons of Drosophila melanogaster and Caenorhabditis elegans.

In summary, we propose that evolution of the ear can best be approached by first considering cellular conservation in the formation of a mechanosensory module, as well as the conservation of developmental mechanisms necessary to produce large assemblies of hair cells and their innervating sensory neurons. This information should be contrasted with the morphological diversification of the acellular structures covering these sensory epithelia and their position in the labyrinth. It seems logical to assume that the splitting of sensory patches predates their functional diversification. Except for the apparent heterochronic shift of sensory neuron development to predate hair cell formation, ear development seems to present a rather clear Haeckelian ontogenetic recapitulation of evolution: evolutionarily late organs, such as the cochlea, also develop last. 
In essence, mechanosensation may have started with mechanotransducer channels in unicellular organisms and/or in basal metazoans (1 in fig. 4). Diploblastic metazoans added the unique association of mechanosensory cell formation, using Pou domain factors and bHLH factors [Grens et al., 1995] and also evolved the grouping of these cells into larger gravistatic organs, possibly employing a single Pax gene that is ancestral to Pax6 and Pax2. Those two Pax genes are now separately involved in ear and eye development ( 2 in fig. 4). In the absence of data for diploblasts, it nevertheless seems safe to conclude that triploblasts added to this existing developmental genetic module the bHLH genes of the atonal family and zinc fin- ger genes, such as senseless and Gata3 (3 in fig. 4). The mechanosensory cells in triploblasts provided the capacity for high frequency detection exploited independently in insects and chordates with the parallel evolution of auditory systems (4 in fig. 4).

\section{Acknowledgements}

This work was supported by grants from NIDCD (R01 DC005590, BF; R01 DC04279 and R01 DC05009, KWB). The authors wish to express their gratitude to Drs. H.J. Bellen, J. Piatigorsky, and B. Degnan for critically reading a previous version of this paper. M.S. Northcutt improved our English.

\section{References}

Alvarez Y, Alonso MT, Vendrell V, Zelarayan LC, Chamero P, Theil T, Bosl MR, Kato S, Maconochie $\mathrm{M}$, Riethmacher $\mathrm{D}$, Schimmang $\mathrm{T}$ (2003) Requirements for FGF3 and FGF10 during inner ear formation. Development 130 6329-633

Andermann P, Ungos J, Raible DW (2002) Neurogenin 1 defines zebrafish cranial sensory ganglia precursors. Dev Biol 251:45-58.

Arkett SA, Mackie GO, Meech RW (1988) Hair cell mechanoreception in a jellyfish Aglantha digitale. J Exp Biol 135:329-342.

Begbie J, Graham A (2001) The ectodermal placodes: a dysfunctional family. Philos Trans R Soc Lond B Biol Sci 356:1655-1660.

Ben-Arie N, Hassan BA, Bermingham NA, Malicki DM, Armstrong D, Matzuk M, Bellen HJ, Zoghbi HY (2000) Functional conservation of atonal and Math1 in the CNS and PNS. Development 127:1039-1048

Bermingham NA, Hassan BA, Price SD, Vollrath MA, Ben-Arie N, Eatock RA, Bellen HJ, Lysakowski A, Zoghbi HY (1999) Math1:an essential gene for the generation of inner ear hair cells. Science 284:1837-1841.

Bertrand N, Castro DS, Guillemot F (2002) Proneural genes and the specification of neural cell types. Nat Rev Neurosci 3:517-530.

Boeda B, El-Amraoui A, Bahloul A, Goodyear R, Daviet L, Blanchard S, Perfettini I, Fath KR, Shorte S, Reiners J, Houdusse A, Legrain P, Wolfrum U, Richardson G, Petit C (2002) Myosin VIIa, harmonin and cadherin 23, three Usher I gene products that cooperate to shape the sensory hair cell bundle. Embo J 21:66896699.

Brown ST, Martin K, Groves AK (2003) Molecular basis of inner ear induction. Curr Top Dev Biol 57:115-149.

Budelmann B (1992) Hearing in nonarthropod invertebrates. In: The Evolutionary Biology of Hearing (Webster DB, Fay RR, Popper AN, eds), pp 141-155. New York, NY: Springer Verlag.
Budelmann BU, Bleckmann H (1988) A lateral line analogue in cephalopods: water waves generate microphonic potentials in the epidermal head lines of Sepia and Lolliguncula. J Comp Physiol A 164:1-5.

Burighel P, Lane NJ, Fabio G, Stefano T, Zaniolo G, Carnevali MD, Manni L (2003) Novel, secondary sensory cell organ in ascidians: in search of the ancestor of the vertebrate lateral line. J Comp Neurol 461:236-249.

Caldwell JC, Eberl DF (2002) Towards a molecular understanding of Drosophila hearing. J Neurobiol 53:172-189.

Cantos R, Cole LK, Acampora D, Simeone A, Wu DK (2000) Patterning of the mammalian cochlea. Proc Natl Acad Sci USA 97:11707-11713.

Davidson EH, Rast JP, Oliveri P, Ransick A, Calestani $\mathrm{C}$, Yuh $\mathrm{CH}$, Minokawa $\mathrm{T}$, Amore $\mathrm{G}$, Hinman V, Arenas-Mena C, Otim O, Brown CT, Livi CB, Lee PY, Revilla R, Rust AG, Pan Z, Schilstra MJ, Clarke PJ, Arnone MI, Rowen L, Cameron RA, McClay DR, Hood L, Bolouri H (2002) A genomic regulatory network for development. Science 295:1669-1678.

de Burlet HM (1934) Vergleichende Anatomie des statoakustischen Organs. a) Die innere Ohrsphäre. In: Handbuch der Vergleichenden Anatomie der Wirbeltiere (Bolk L, Göppert E, Kallius E, Lubosch W, eds), pp 1293-1432. Berlin: Urban and Schwarzenberg.

Dehal P, Satou Y, Campbell RK, Chapman J, Degnan B, De Tomaso A, Davidson B, Di Gregorio A, Gelpke M, Goodstein DM, Harafuji N, Hastings KE, Ho I, Hotta K, Huang W, Kawashima T, Lemaire P, Martinez D, Meinertzhagen IA, Necula S, Nonaka M, Putnam N, Rash S, Saiga H, Satake M, Terry A, Yamada L, Wang HG, Awazu S, Azumi K, Boore J, Branno M, Chin-Bow S, DeSantis R, Doyle S, Francino P, Keys DN, Haga S, Hayashi H, Hino K, Imai KS, Inaba K, Kano S, Kobayashi K, Kobayashi M, Lee BI, Makabe KW, Manohar C, Matassi G, Medina M, Mochizuki Y, Mount S, Morishita T, Miura S, Nakayama A, Nishizaka
S, Nomoto H, Ohta F, Oishi K, Rigoutsos I, Sano M, Sasaki A, Sasakura Y, Shoguchi E, Shin-i T, Spagnuolo A, Stainier D, Suzuki MM, Tassy O, Takatori N, Tokuoka M, Yagi K, Yoshizaki F, Wada S, Zhang C, Hyatt PD, Larimer F, Detter C, Doggett N, Glavina T, Hawkins T, Richardson P, Lucas S, Kohara Y, Levine M, Satoh N, Rokhsar DS (2002) The draft genome of Ciona intestinalis: insights into chordate and vertebrate origins. Science 298: 2157-2167.

Dong PD, Todi SV, Eberl DF, Boekhoff-Falk G (2003) Drosophila spalt/spalt-related mutants exhibit Townes-Brocks' syndrome phenotypes. Proc Natl Acad Sci USA 100:10293-10298.

Farinas I, Jones KR, Tessarollo L, Vigers AJ, Huang E, Kirstein M, de Caprona DC, Coppola V, Backus C, Reichardt LF, Fritzsch B (2001) Spatial shaping of cochlear innervation by temporally regulated neurotrophin expression. J Neurosci 21:6170-6180.

Favor J, Sandulache R, Neuhauser-Klaus A, Pretsch W, Chatterjee B, Senft E, Wurst W, Blanquet V, Grimes P, Sporle R, Schughart K (1996) The mouse Pax2(1Neu) mutation is identical to a human PAX2 mutation in a family with renal-coloboma syndrome and results in developmental defects of the brain, ear, eye, and kidney. Proc Natl Acad Sci USA 93: 13870-13875.

Friedman TB, Sellers JR, Avraham KB (1999) Unconventional myosins and the genetics of hearing loss. Am J Med Genet 89:147-157.

Fritzsch B (1987) The inner ear of the coelacanth fish Latimeria has tetrapod affinities. Nature 327:153-154

Fritzsch B (1988) The amphibian octavo-lateralis system and its regressive and progressive evolution. Acta Biol Hung 39:305-322. 
Fritzsch B (1992) The water-to-land transition: Evolution of the tetrapod basilar papilla, middle ear and auditory nuclei. In: The Evolutionary Biology of Hearing (Webster DB, Fay RR, Popper AN, eds), pp 351-375. New York: Springer-Verlag.

Fritzsch B (1999) Hearing in two worlds: Theoretical and realistic adaptive changes of the aquatic and terrestrial ear for sound reception In: Comparative Hearing: Fish and Amphibians (Fay RR, Popper AN, eds), pp 15-42. New York: Springer-Verlag.

Fritzsch B (2003) The ear of Latimeria chalumnae revisited. Zoology 106:243-248.

Fritzsch B, Beisel KW (2001) Evolution and development of the vertebrate ear. Brain Res Bull 55:711-721.

Fritzsch B, Beisel KW (2003) Molecular conservation and novelties in vertebrate ear development. Curr Top Dev Biol 57:1-44.

Fritzsch B, Wake MH (1988) The inner ear of gymnophione amphibians and its nerve supply: a comparative study of regressive events in a complex sensory system. Zoomorphologie 108 . 210-217.

Fritzsch B, Barald K, Lomax M (1998) Early embryology of the vertebrate ear. In: Springer Handbook of Auditory Research. Vol XII. Development of the Auditory System (Fay RR, ed), pp 80-145. New York: Springer-Verlag.

Fritzsch B, Beisel KW, Bermingham NA (2000) Developmental evolutionary biology of the vertebrate ear: conserving mechanoelectric transduction and developmental pathways in diverging morphologies. Neuroreport 11:R35-44.

Fritzsch B, Beisel KW, Jones K, Farinas I, Maklad A, Lee J, Reichardt LF (2002) Development and evolution of inner ear sensory epithelia and their innervation. J Neurobiol 53:143156.

Fritzsch B, Signore M, Simeone A (2001) Otx 1 null mutant mice show partial segregation of sensory epithelia comparable to lamprey ears. Dev Genes Evol 211:388-396.

Garcia-Anoveros J, Samad TA, Zuvela-Jelaska L, Woolf CJ, Corey DP (2001) Transport and localization of the DEG/ENaC ion channel $\mathrm{BNaClalpha}$ to peripheral mechanosensory terminals of dorsal root ganglia neurons. J Neurosci 21:2678-2686.

Giot L, Bader JS, Brouwer C, Chaudhuri A, Kuang B, Li Y, Hao YL, Ooi CE, Godwin B, Vitols E, Vijayadamodar G, Pochart P, Machineni $H$, Welsh M, Kong Y, Zerhusen B, Malcolm R, Varrone Z, Collis A, Minto M, Burgess S, McDaniel L, Stimpson E, Spriggs F, Williams J, Neurath K, Ioime N, Agee M, Voss E, Furtak K, Renzulli R, Aanensen N, Carrolla S, Bickelhaupt E, Lazovatsky Y, DaSilva A, Zhong J, Stanyon CA, Finley RL, Jr., White KP, Braverman M, Jarvie T, Gold S, Leach M, Knight J, Shimkets RA, McKenna MP, Chant J, Rothberg JM (2003) A protein interaction map of Drosophila melanogaster. Science 302:17271736.
Goodyear R, Richardson GP (1999) The ankle-link antigen: an epitope sensitive to calcium chelation associated with the hair-cell surface and the calycal processes of photoreceptors. J Neurosci 19:3761-3772.

Goodyear RJ, Richardson GP (2002) Extracellular matrices associated with the apical surfaces of sensory epithelia in the inner ear: molecular and structural diversity. J Neurobiol 53:212227.

Grens A, Mason E, Marsh JL, Bode HR (1995) Evolutionary conservation of a cell fate specification gene: the Hydra achaete-scute homolog has proneural activity in Drosophila. Development 121:4027-4035.

Groves AK, Bronner-Fraser M (2000) Competence, specification and commitment in otic placode induction. Development 127:34893499.

Hannibal J, Hindersson P, Knudsen SM, Georg B, Fahrenkrug J (2002) The photopigment melanopsin is exclusively present in pituitary adenylate cyclase-activating polypeptide-containing retinal ganglion cells of the retinohypothalamic tract. J Neurosci 22:RC191.

Hassan BA, Bellen HJ (2000) Doing the MATH: is the mouse a good model for fly development? Genes Dev 14:1852-1865.

Hatini V, Ye X, Balas G, Lai E (1999) Dynamics of placodal lineage development revealed by targeted transgene expression. Dev Dyn 215:332343.

Hekimi S, Guarente L (2003) Genetics and the specificity of the aging process. Science 299: 1351-1354.

Holland LZ, Schubert M, Holland ND, Neuman T (2000) Evolutionary conservation of the presumptive neural plate markers AmphiSox 1/2/3 and AmphiNeurogenin in the invertebrate chordate amphioxus. Dev Biol 226:18-33.

Inoue C, Bae SK, Takatsuka K, Inoue T, Bessho Y, Kageyama R (2001) Math6, a bHLH gene expressed in the developing nervous system, regulates neuronal versus glial differentiation. Genes Cells 6:977-986.

Jafar-Nejad H, Acar M, Nolo R, Lacin H, Pan H, Parkhurst SM, Bellen HJ (2003) Senseless acts as a binary switch during sensory organ precursor selection. Genes Dev 17:2966-2978.

Jorgensen JM (1989) Evolution of octavolateralis sensory cells. In: The Mechanosensory Lateral Line. Neurobiology and Evolution (Coombs S, Goerner P, Muenz H, eds), pp 99-115. New York: Springer-Verlag.

Jorgensen JM, Locket NA (1995) The inner ear of the echidna Tachyglossus aculeatus: the vestibular sensory organs. Proc R Soc Lond B 260: 183-189.

Karis A, Pata I, van Doorninck JH, Grosveld F, de Zeeuw CI, de Caprona D, Fritzsch B (2001) Transcription factor GATA-3 alters pathway selection of olivocochlear neurons and affects morphogenesis of the ear. J Comp Neurol 429: 615-630.

Kavaler J, Fu W, Duan H, Noll M, Posakony JW (1999) An essential role for the Drosophila Pax2 homolog in the differentiation of adult sensory organs. Development 126:2261-2272.
Keresztes G, Mutai H, Heller S (2003a) TMC and EVER genes belong to a larger novel family, the TMC gene family encoding transmembrane proteins. BMC Genomics 4:24.

Keresztes G, Mutai H, Hibino H, Hudspeth AJ, Heller S (2003b) Expression patterns of the RGS9-1 anchoring protein R9AP in the chicken and mouse suggest multiple roles in the nervous system. Mol Cell Neurosci 24:687-695.

Kiefer SM, Ohlemiller KK, Yang J, McDill BW, Kohlhase J, Rauchman M (2003) Expression of a truncated Sall1 transcriptional repressor is responsible for Townes-Brocks syndrome birth defects. Hum Mol Genet 12:2221-2227.

Kim J, Chung YD, Park DY, Choi S, Shin DW, Soh H, Lee HW, Son W, Yim J, Park CS, Kernan MJ, Kim C (2003) A TRPV family ion channel required for hearing in Drosophila. Nature 424: 81-84.

Kozmik Z, Daube M, Frei E, Norman B, Kos L, Dishaw LJ, Noll M, Piatigorsky J (2003) Role of Pax Genes in Eye Evolution. A Cnidarian PaxB Gene Uniting Pax2 and Pax6 Functions. Dev Cell 5:773-785.

Lewis ER, Leverenz EL, Bialek WS (1985) The Vertebrate Inner Ear. Boca Raton FL: CRC Press.

Liedtke W, Friedman JM (2003) Abnormal osmotic regulation in trpv4-/- mice. Proc Natl Acad Sci USA 100:13698-13703.

Liedtke W, Tobin DM, Bargmann CI, Friedman JM (2003) Mammalian TRPV4 (VR-OAC) directs behavioral responses to osmotic and mechanical stimuli in Caenorhabditis elegans. Proc Natl Acad Sci USA 100(suppl 2):1453114536.

Lim DJ, Rueda J (1992) Structural development of the cochlea. In: Development of Auditory and Vestibular Systems, 2nd Ed (Romand R, ed), pp 33-58. Amsterdam: Elsevier.

Lowe CJ, Wu M, Salic A, Evans L, Lander E, Stange-Thomann N, Gruber CE, Gerhart J, Kirschner M (2003) Anteroposterior patterning in hemichordates and the origins of the chordate nervous system. Cell 113:853-865.

Ma Q, Anderson DJ, Fritzsch B (2000) Neurogenin 1 null mutant ears develop fewer, morphologically normal hair cells in smaller sensory epithelia devoid of innervation. J Assoc Res Otolaryngol 1:129-143.

Ma Q, Chen Z, del Barco Barrantes I, de la Pompa JL, Anderson DJ (1998) neurogenin 1 is essential for the determination of neuronal precursors for proximal cranial sensory ganglia. Neuron 20:469-482.

Mackie GO, Singla CL (2003) The capsular organ of Chelyosoma productum (Ascidiacea: Corellidae): a new tunicate hydrodynamic sense organ. Brain Behav Evol 61:45-58.

Maklad A, Fritzsch B (2003) Development of vestibular afferent projections into the hindbrain and their central targets. Brain Res Bull 60: 497-510.

Markl H (1974) The perception of gravity and of angular acceleration in invertebrates. In: Handbook of Sensory Physiology (Kornhuber HH, ed), pp 17-74. Berlin: Springer-Verlag. 
Morsli H, Choo D, Ryan A, Johnson R, Wu DK (1998) Development of the mouse inner ear and origin of its sensory organs. J Neurosci 18 : 3327-3335.

Morsli H, Tuorto F, Choo D, Postiglione MP, Simeone A, Wu DK (1999) Otx1 and Otx2 activities are required for the normal development of the mouse inner ear. Development $126: 2335-2343$.

Mutai H, Heller S (2003) Vertebrate and invertebrate TRPV-like mechanoreceptors. Cell Calcium 33:471-478

Niwa N, Hiromi Y, Okabe M (2004) A conserved developmental program for sensory organ formation in Drosophila melanogaster. Nat Genet 36:293-297.

Noramly S, Grainger RM (2002) Determination of the embryonic inner ear. J Neurobiol 53:100 128.

Norris HW (1892) Studies on the development of the ear in Amblystoma. I. Development of the auditory vesicle. J Morphol 7:23-34

Northcutt RG (1980) Central auditory pathways in anamniotic vertebrates. In: Comparative Studies of Hearing in Vertebrates (Popper AN, Fay RR, eds), pp 79-118. New York: Springer-Verlag.

O'Brien EK, Degnan B (2003) Expression of Pax 258 in the gastropod statocyst: insights into the antiquity of metazoan geosensory organs. Evol Dev 5:572-578.

Pauley S, Wright TJ, Pirvola U, Ornitz D, Beisel K, Fritzsch B (2003) Expression and function of FGF10 in mammalian inner ear development. Dev Dyn 227:203-215.

Piatigorsky J (2003) Gene sharing, lens crystallins and speculations on an eye/ear evolutionary relationship. Integ Comp Biol 43:492-499.

Pispa J, Thesleff I (2003) Mechanisms of ectodermal organogenesis. Dev Biol 262:195-205.

Raft S, Nowotschin S, Liao J, Morrow BE (2004) Suppression of neural fate and control of inner ear morphogenesis by Tbx 1 . Development 131 1801-1812.

Retzius G (1884) Das Gehörorgan der Wirbeltiere: II. Das Gehörorgan der Amnioten. Stockholm: Samson und Wallin.

Riley BB (2003) Genes controlling the development of the zebrafish inner ear and hair cells. Curr Top Dev Biol 57:357-388.

Sarasin P, Sarasin F (1892) Über das Gehörorgan der Caeciliiden. Anat Anz 7:812-815.
Sato M, Saigo K (2000) Involvement of pannier and $\mathrm{u}$-shaped in regulation of decapentaplegicdependent wingless expression in developing Drosophila notum. Mech Dev 93:127-138.

Schlosser G (2002) Development and evolution of lateral line placodes in amphibians. I. Development. Zoology 105:119-146.

Schlosser G, Kintner C, Northcutt RG (1999) Loss of ectodermal competence for lateral line placode formation in the direct developing frog Eleutherodactylus coqui. Dev Biol 213:354369.

Solomon KS, Kudoh T, Dawid IB, Fritz A (2003) Zebrafish foxil mediates otic placode formation and jaw development. Development 130: 929-940.

Strassmaier M, Gillespie PG (2002) The hair cell's transduction channel. Curr Opin Neurobiol 12: 380-386.

Streit A (2002) Extensive cell movements accompany formation of the otic placode. Dev Biol 249:237-254.

Sun Y, Kanekar SL, Vetter ML, Gorski S, Jan YN, Glaser T, Brown NL (2003) Conserved and divergent functions of Drosophila atonal, amphibian, and mammalian Ath5 genes. Evol Dev 5:532-541.

Sutherland D, Samakovlis C, Krasnow MA (1996) Branchless encodes a Drosophila FGF homolog that controls tracheal cell migration and the pattern of branching. Cell 87:1091-1101.

Torres M, Giraldez F (1998) The development of the vertebrate inner ear. Mech Dev 71:5-21.

van Bergeijk WA (1966) Evolution of the sense of hearing in vertebrates. Am Zool 6:371-377.

Van Esch H, Devriendt K (2001) Transcription factor GATA3 and the human HDR syndrome. Cell Mol Life Sci 58:1296-1300.

Walker RG, Willingham AT, Zuker CS (2000) A Drosophila mechanosensory transduction channel. Science 287:2229-2234.

Wallis D, Hamblen M, Zhou Y, Venken KJ, Schumacher A, Grimes HL, Zoghbi HY, Orkin SH, Bellen HJ (2003) The zinc finger transcription factor Gfi1, implicated in lymphomagenesis, is required for inner ear hair cell differentiation and survival. Development 130:221-232.

Wang SW, Kim BS, Ding K, Wang H, Sun D, Johnson RL, Klein WH, Gan L (2001) Requirement for math 5 in the development of retinal ganglion cells. Gene Dev 15:24-29.

Wang VY, Hassan BA, Bellen HJ, Zoghbi HY (2002) Drosophila atonal fully rescues the phenotype of Math1 null mice: new functions evolve in new cellular contexts. Curr Biol 12: 1611-1616.
Weil D, Levy G, Sahly I, Levi-Acobas F, Blanchard S, El-Amraoui A, Crozet F, Philippe H, Abitbol M, Petit C (1996) Human myosin VIIA responsible for the Usher 1B syndrome: a predicted membrane-associated motor protein expressed in developing sensory epithelia. Proc Natl Acad Sci USA 93:3232-3237.

Welsh MJ, Price MP, Xie J (2002) Biochemical basis of touch perception: mechanosensory function of degenerin/epithelial $\mathrm{Na}+$ channels. J Biol Chem 277:2369-2372.

Wever EG (1974) The evolution of vertebrate hearing. In: Auditory System (Keidel WD, Neff WD, eds), pp 423-454. Berlin: Springer-Verlag.

Wright TJ, Mansour SL (2003) Fgf3 and Fgf10 are required for mouse otic placode induction. Development 130:3379-3390.

Wu HH, Ivkovic S, Murray RC, Jaramillo S, Lyons KM, Johnson JE, Calof AL (2003) Autoregulation of Neurogenesis by GDF11. Neuron 37: 197-207.

Xu PX, Adams J, Peters H, Brown MC, Heaney S, Maas R (1999a) Eya1-deficient mice lack ears and kidneys and show abnormal apoptosis of organ primordia. Nat Genet 23:113-117.

Xu PX, Zhang X, Heaney S, Yoon A, Michelson AM, Maas RL (1999b) Regulation of Pax6 expression is conserved between mice and flies. Development 126:383-395.

Yager DD (1999) Structure, development, and evolution of insect auditory systems. Microsc Res Tech 47:380-400.

Yamada L, Shoguchi E, Wada S, Kobayashi K, Mochizuki Y, Satou Y, Satoh N (2003) Morpholino-based gene knockdown screen of novel genes with developmental function in Ciona intestinalis. Development 130:6485-6495.

Zhao C, Emmons SW (1995) A transcription factor controlling development of peripheral sense organs in C. elegans. Nature 373:74-78.

Zheng W, Huang L, Wei ZB, Silvius D, Tang B, Xu PX (2003) The role of Six 1 in mammalian auditory system development. Development 130:3989-4000.

Zine A, Aubert A, Qiu J, Therianos S, Guillemot F, Kageyama R, de Ribaupierre F (2001) Hes1 and Hes 5 activities are required for the normal development of the hair cells in the mammalian inner ear. J Neurosci 21:4712-4720. 